\title{
TIMING OF PALAEOPROTEROZOIC CRUSTAL SHEARING IN THE CENTRAL FENNOSCANDIAN SHIELD ACCORDING TO U-Pb DATA FROM ASSOCIATED GRANITOIDS, FINLAND
}

\author{
MATTI VAASJOKI, AULIS KÄRKI and KAUKO LAAJOKI
}

VAASJOKI, MATTI, KÄRKI, AULIS and LAAJOKI, KAUKO 2001. Timing of Palaeoproterozoic crustal shearing in the central Fennoscandian Shield according to U-Pb data from associated granitoids, Finland. Bulletin of the Geological Society of Finland 73, Parts 1-2, 87-101.

Granitoids in the Finnish part of the Fennoscandian Shield were created by numerous Archaean and Palaeoproterozoic tectonic events. Late phases of $\mathrm{Pa}$ laeoproterozoic, Svecokarelian deformation created ductile, crustal-scale shear zones, of which the N-S striking Hirvaskoski Shear Zone and the NE-SW striking Oulujärvi Shear Zone were strongly affected by the latest deformation stages, $\mathrm{D}_{3}$ and $\mathrm{D}_{4}$. These shear tectonic events deformed ductilely prekinematic granitoids and caused intrusion of synkinematic igneous rocks, but the $\mathrm{D}_{3}$ and $\mathrm{D}_{4}$ fault rocks are also penetrated by postkinematic intrusives.

Archaean granitoids behaved mostly as rigid blocks unaffected by Palaeoproterozoic deformation. However, inherited Archaean zircons occur in some obviously Proterozoic granitoids, and others contain heterogeneous zircon populations. Granitoids lacking structures of the earliest deformations, $\mathrm{D}_{1}$ and $\mathrm{D}_{2}$, contain inherited zircon populations partially reset during the Svecokarelian orogeny and have been sheared ductilely during stages $\mathrm{D}_{3}$ and $\mathrm{D}_{4}$. Granitic rocks yielding zircon ages of 1.82-1.80 Ga show no features associated with these shearing events and penetrate the $\mathrm{D}_{4}$ fault rocks setting a minimum age for these deformation events. This age marks also the end of convergent tectonics in the central Fennoscandian Shield. Monazite data from a variety of rocks demonstrates a regional cooling below the $600^{\circ} \mathrm{C}$ isotherm at $1.8 \mathrm{Ga}$.

Key words: shear zones, granites, deformation, absolute age, $\mathrm{U} / \mathrm{Pb}$, zircon, monazite, Paleoproterozoic, Hirvaskoski, Oulujärvi, Finland

Matti Vaasjoki: Geological Survey of Finland, Box 96, FIN 02151 Espoo, Finland

E-mail:matti.vaasjoki@gsf.fi

Aulis Kärki and Kauko Laajoki: University of Oulu, Box 3000, FIN-90401 Oulu, Finland 


\section{INTRODUCTION}

This paper deals with radiometric age determinations from granitoid rocks within major Palaeoproterozoic shear zones in central Finland (Fig. 1; Kärki et al. 1993, Kärki 1995). Archaean and Palaeoproterozoic granites occur as bodies of variable shapes and sizes within the shear zones and form a remarkable proportion of them. Some granitoids predate the shear zone formation and are occasionally deformed into fault rocks, but there are also intrusions developed during and after the shearing periods. Shear related granitoids can offer a good means of evaluating ages of tectonic events (see eg. Hutton \& Reavy 1992, Scott et al. 1993), but problems may arise in determining exact age relationships between various phases of intrusion and deformation (eg. Paterson \& Tobisch 1988, Guglielmo 1993).

Archaean granitoids occur as blocks of various sizes within the shear zones, but Palaeoproterozoic granitoids form also considerable proportions of these ductile shear zones. Typically they are coarsegrained pegmatites and mainly undeformed leucocratic or biotite-bearing granites locally sheared into mylonites showing similar structures as adjacent mylonitic paragneisses. The Manamansalo Complex is a large Archaean block that belongs to the Oulujärvi Shear Zone (Fig. 2) and its Archaean structures are occasionally overprinted by Palaeoproterozoic ones. Smaller blocks of probable Archaean age occur throughout the shear zones but, due to Palaeoproterozoic deformation and formation of secondary potassium feldspar, discriminating between granitoids of either Archaean or Palaeoproterozoic origin is often difficult.

\section{GEOLOGICAL SETTING AND GRANI- TOID TYPES}

The most significant Precambrian crustal units in the Finnish part of the central Fennoscandian Shield (Gorbatschev \& Bogdanova 1993) are: (1) the Kola Province, which occupies the area northeast of the Lapland Granulite Belt (Fig. 1) and is largely an Archaean granitoid-greenstone terrain partly rejuvenated in Palaeoproterozoic times (Meriläinen 1976, Kesola 1991, Hanski 1993); (2) the Karelian Province, lying between the Kola Province and the Svecofennides and consisting of Archaean granitoid gneisses and greenstones (Hyppönen 1983, Luukkonen 1988) with Palaeoproterozoic cover rocks known as the Karelian Formations (Laajoki 1986 and 1991, Kohonen \& Marmo 1992) and penetrated by a number of dyke swarms (Vuollo 1994) and infracrustal rocks (Huhma 1986); and (3) the Svecofennian Province, composed of Palaeoproterozoic infracrustal rocks (Suominen 1991, Vaasjoki 1996) with deformed metasediments of mixed provenance (Huhma et al. 1991, Claesson et al. 1993) and mafic-felsic metavolcanics of arc affinity (Gaál \& Gorbatschev 1987, Kähkönen 1989).

The boundary between the Karelian and Svecofennian Provinces is relatively well defined, although its exact nature is disputed. It lies along the Raahe-Ladoga zone (Kahma 1978, Gaál \& Gorbatschev 1987, Korsman 1988), and Sm-Nd data on igneous rocks (Lahtinen \& Huhma 1997) indicate that it is fairly sharp in Finland. Recent data from the Salahmi schist belt (Pietikäinen \& Vaasjoki 1999) indicate that major penetrative movements had ceased by $1882 \pm 4 \mathrm{Ma}$, but that crustal temperatures cooled permanently below c. $500^{\circ} \mathrm{C}$ much later, about $1820 \mathrm{Ma}$ ago.

The Karelian Province was affected by Svecokarelian progressive deformation, which created its major structural features in four main stages (eg. Kärki et al. 1993). The structural evolution is divided into an early phase that involved the formation of thrust nappes at the craton margin and the creation of related folds of pre- $\mathrm{D}_{1}$ and $D_{1}$ stages (eg. Ward 1987), followed by more upright folding in $\mathrm{D}_{2}$ (eg. Luukas 1991). Younger phases of shear tectonics then produced new shear zones and reactivated older ones in the northern and central Fennoscandian Shield. The generation of the dextral, N-S-trending ductile shears of the Hirvaskoski Shear Zone (HSZ) was associated with deformation stage $D_{3}$ which is described in detail by Kärki et al. (1993). Stage $\mathrm{D}_{4}$ caused E$\mathrm{W}$-trending folding and created dextral NW-SEtrending and sinistral NE-SW-trending shear struc- 

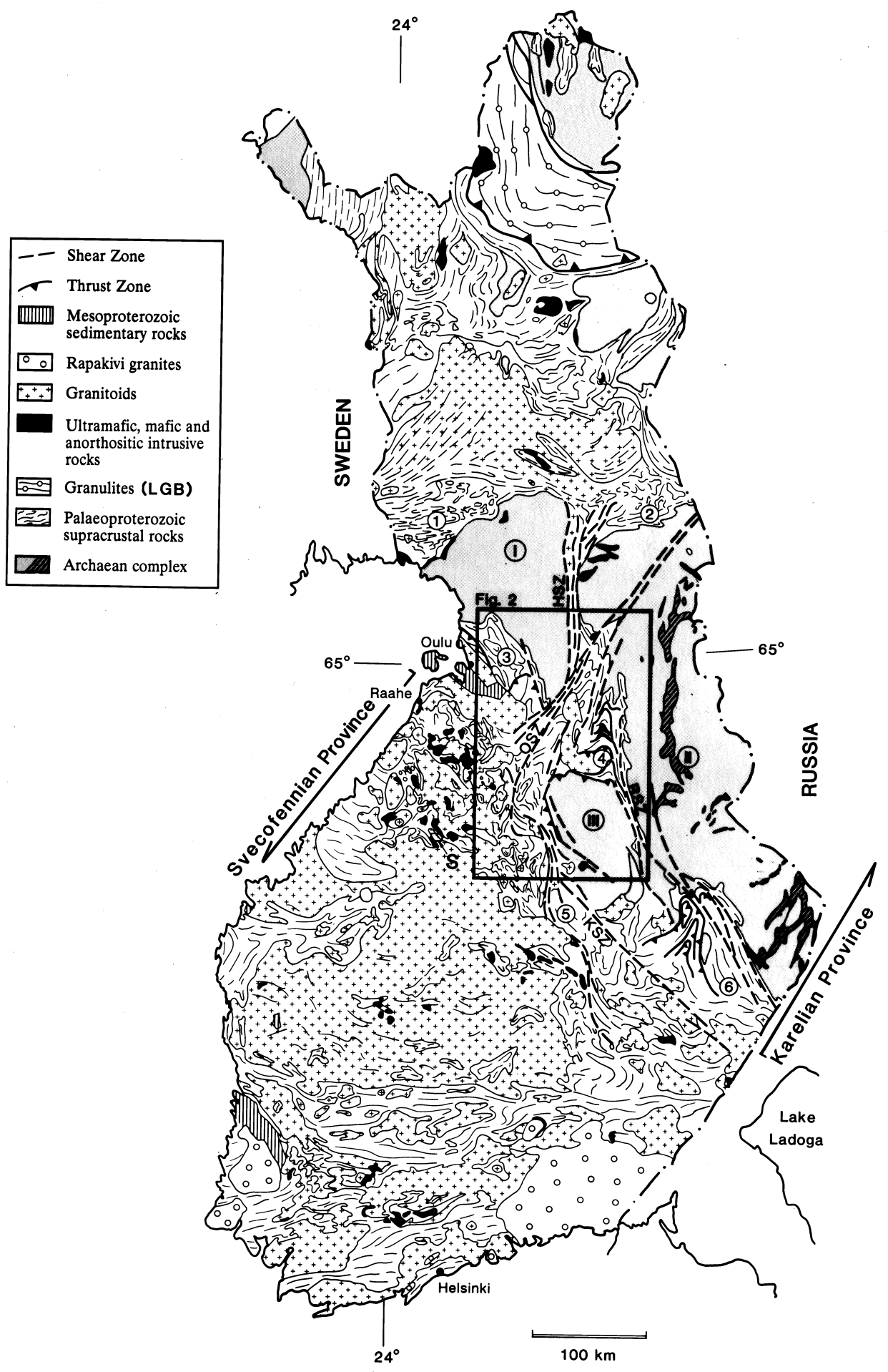

Fig. 1. Generalized geological map of Finland indicating the locations of the Oulujärvi (OSZ), Hirvaskoski (HSZ), Rautavaara (RSZ) and Kuopio (KSZ) shear zones. LGB=Lapland Granulite Belt. 


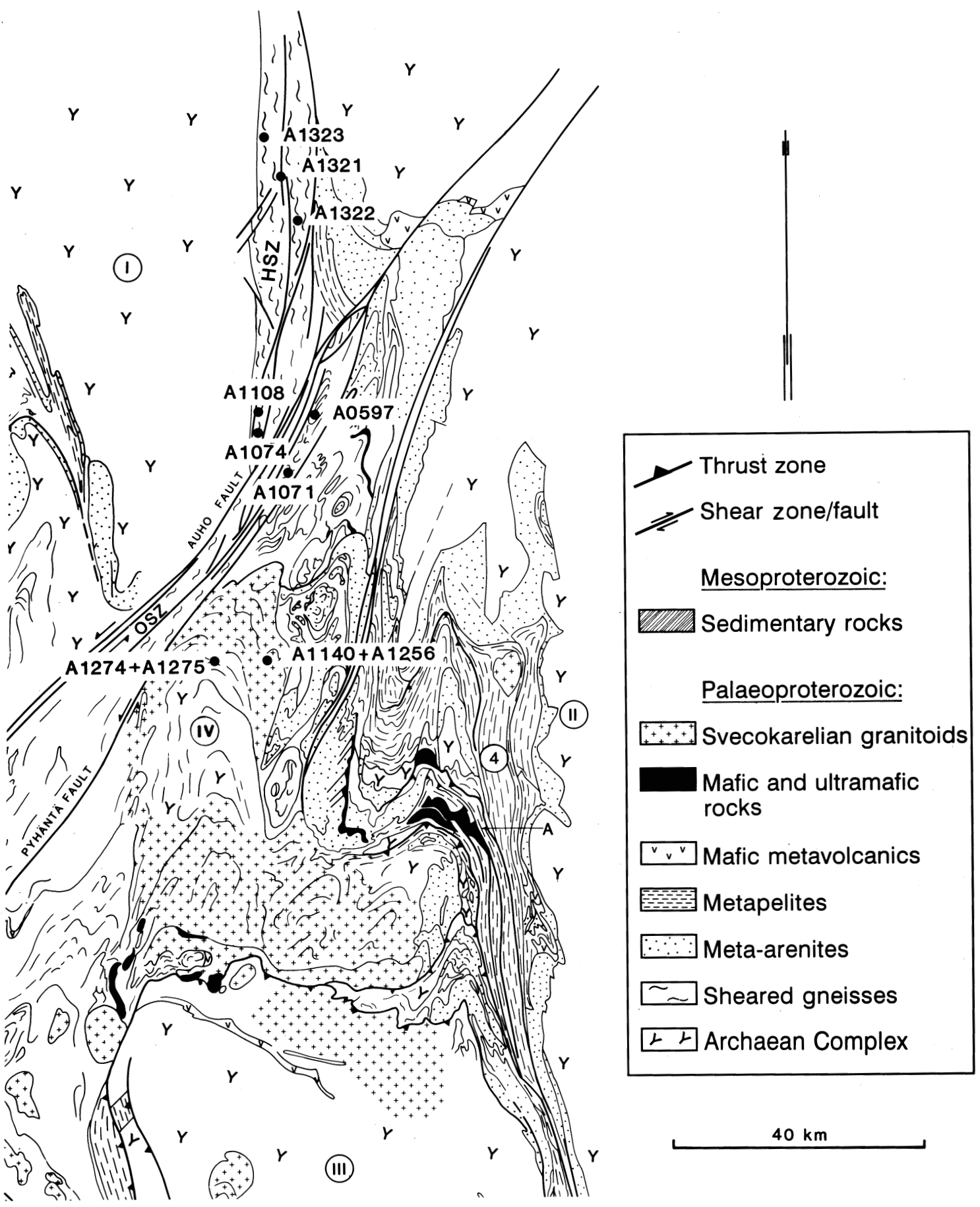

Fig. 2. The study area and the locations of the sampling sites. Surrounding Archaean blocks: I. Pudasjärvi, II. Kuhmo, III. Iisalmi. IV. Manamansalo Complex 4. Puolanka Schist Zone. HSZ and OSZ as in Fig. 1. After Kärki (1995). 
tures, while $\mathrm{S}_{4}$ foliation is a ubiquitous feature in many older rocks (Kärki \& Laajoki 1995). Most prominent of these $\mathrm{D}_{4}$ zones is the crustalscale, sinistral, NE-SW striking Oulujärvi Shear Zone (OSZ) in central Finland (Kärki 1995). Many Palaeoproterozoic granitoids are structurally controlled and associated with the evolution of these large-scale shear zones (see Kärki \& Laajoki 1990).

A large part of the Karelian Province consists of late Archaean granitoids and migmatitic gneisses affected occasionally by Palaeoproterozoic tectonics and structural development. The proportion of Palaeoproterozoic granitoids intruding the Karelian Formations is also large especially in Kainuu and Lapland (Fig. 1). U-Pb ages on zircons indicate that major peaks of magmatic activity and concomitant granitoid emplacement occurred as discrete episodes around 3.1, 2.8-2.7, 1.9-1.8 and 1.7-1.5 Ga ago (Vaasjoki \& Huhma 1992).

The dominant granitoid types within the Finnish Archaean are complex migmatites with tonalitic, trodhjemitic, granodioritic or granitic palaeosomes invaded by tonalitic to granitic neosomes (Barbey \& Martin 1987, Horneman et al. 1988). The oldest tonalites are about $3100 \mathrm{Ma}$ old, and are found in Lapland (Kröner et al. 1981) and central Finland (Paavola 1986). At least the northern occurrence has yielded $\mathrm{Sm}-\mathrm{Nd}$ data suggesting a previous crustal history (Jahn et al. 1984). A number of migmatites give U-Pb zircon ages of 2830 Ma (Martin et al. 1983, Luukkonen 1985, Vaasjoki et al. 1999). The most widespread group is nevertheless that of the 2750-2720 Ma migmatites and granitoids which intrude the greenstone belts in eastern Finland (Hyppönen 1983, Vaasjoki et al. 1993 and 1999). Many of these rocks exhibit titanite ages of 2700-2670 Ma, which may indicate either a post-emplacement thermal episode or cooling due to a regional uplift.

Palaeoproterozoic granitoids are encountered throughout the area affected by the Svecokarelian orogeny, and their subdivision is commonly based on their relationship to orogenic stages. Thus they are usually described as synorogenic, late orogenic or postorogenic (Simonen 1980, Nurmi \& Haapala 1986), although the existence of an intraorogenic group in southern Finland has been proposed (Suominen 1991).

The Svecokarelian synorogenic granitoids occur mainly within the Svecofennian Province as stocks and batholiths intruding the volcano-sedimentary sequences. Their zircon U-Pb ages vary from 1930 to $1860 \mathrm{Ma}$, with a pronounced maximum at 1890-1880 Ma (Vaasjoki 1996 and references therein). Their monazite and titanite ages are more variable, however, ranging from 1880 to $1800 \mathrm{Ma}$ (ibid.) with maxima at 1880-1860 and 1830-1800 Ma, demonstrating a variation between blocks in the time of either a secondary thermal episode or a regional uplift.

The synorogenic granitoids exhibit I-type characteristics and typical polyphase deformation sequences (Nironen \& Front 1992). Their $\varepsilon_{\mathrm{Nd}}$ values range from 0 to +3 within the Svecofennian Province and from -4 to -1 within the Karelian Province (Huhma 1986, Patchett \& Kouvo 1986). Tonalites and trondhjemites are generally slightly more primitive than granites. The markedly lower values for the granitoids within the Karelian Province are best explained by a mixing of Archaean crustal material into juvenile Palaeoproterozoic melts.

Late orogenic granitoids often exhibit S-type characteristics (Nurmi \& Haapala 1986). They consist of pegmatites, quartz monzonites and granites, which often occur as diapiric bodies or form neosomes in migmatites. They are highly heterogeneous in age, exhibiting a range of 1880$1830 \mathrm{Ma}$, with the younger ones occurring in southern Finland (Vaasjoki \& Sakko 1988, Suominen 1991). Their $\varepsilon_{\mathrm{Nd}}$ values range from -9 for the Karelian granitoids to 0 for the Svecofennian ones (Huhma 1986).

Postorogenic granitoids form the most heterogeneous age group within the Svecokarelian granitoids. In central Finland, they are coeval with the synorogenic intrusions within the margins of analytical error, but in southern Finland they are clearly younger and it is probable that the 1830 Ma migmatizing event and subsequent postorogenic magmatism at $1820-1790 \mathrm{Ma}$ are not directly connected with the peak of the Svecokarelian orogeny (Vaasjoki 1996). The forms of the 
postorogenic granitoid occurrences vary greatly, including composite stocks, ring intrusions and dykes in the Svecofennian domain and multiple batholiths, stocks and neosomes of migmatites in the Karelian domain. The postorogenic Karelian granitoids also exhibit evidence of a prolonged crustal history, while those of the Svecofennian domain are mainly made up of juvenile mantlederived material (Huhma 1986).

\section{GRANITOIDS IN THE SHEAR ZONES AND SAMPLE MATERIAL}

Our main aim was to date the granitoid rocks of the Palaeoproterozoic Hirvaskoski and Oulujärvi Shear Zones in central Finland by U-Pb analyses of zircons and to evaluate the timing of the $\mathrm{D}_{3}$ and $\mathrm{D}_{4}$ shearing events by analyses of monazite. Granitoids form a significant part of both shear zones (Kärki \& Laajoki 1990) and the samples represent a variety of Archaean and Palaeoproterozoic intrusions within the study area (Fig. 2, Table 1) which form two distinct groups in relation to the shearing events and their associated fault structures. The members of the first group show deformation structures related to the $\mathrm{D}_{3}$ and $\mathrm{D}_{4}$ stages, whereas the other group consists of rocks which are either undeformed or penetrate the ductile structures.

The deformed granitoids are either Archaean or Palaeoproterozoic in age. At least some parts of these units have been deformed in solid state into fault rocks and exhibit ductile defor- mation structures such as mylonitic and $\mathrm{S}-\mathrm{C}$ mylonitic $\mathrm{S}_{3}$ and $\mathrm{S}_{4}$ foliations. Archaean granitoids exist as blocks which behaved mostly as competent, rigid bodies during the Palaeoproterozoic deformation. Some parts of them exhibit, however, penetrative foliation associated with the formation of the shear zones. Palaeoproterozoic granitoids within the shear zone systems are mainly granitic and form elongated bodies trending parallel to the zones (Kärki \& Laajoki 1990). At least some parts of these granites were sheared and did participate in the formation of the shear zones in a ductile manner.

Sample A1074 (Kuvajavaara paragneiss) was taken from the Hirvaskoski Shear Zone (HSZ) and represents a banded biotite-bearing quartz-feldspar gneiss which was intensely folded at the $\mathrm{D}_{3}$ stage. The sample was supposed to represent a volcanogenic paragneiss.

Sample A1323 (Sotkavaara banded granite) is a medium-grained biotite granite from the HSZ. It is penetratively deformed and shows mylonitic $\mathrm{S}_{3}$ and less pronounced $\mathrm{S}_{4}$ foliations.

Sample A597 (Saariaho granite) from the centre of the OSZ represents an oval granite body intensely sheared at its margins. The granite is equigranular, medium grained and contains minor biotite. Occasionally, it may exhibit an $\mathrm{S}_{4}$ foliation as the only deformation structure.

Sample A1071 (Avainlampi diorite) is from a homogeneous, medium-grained and foliated dioritic dyke approximately half a metre wide intruding into the paragneisses of the OSZ. The dyke

Table 1. Geographic locations of analyzed samples.

\begin{tabular}{|c|c|c|c|c|c|}
\hline Sample & Location & Rock type & Map & Northing & Easting \\
\hline A0597 & Saariaho & Granite & 344207 & 7204.90 & 3526.40 \\
\hline A1008 & Kivivaara & Granite pegmatite & 344205 & 7200.49 & 3516.47 \\
\hline A1071 & Avainlampi & Diorite & 344207 & 7191.16 & 3521.74 \\
\hline A1074 & Kuvajavaara & Paragneiss & 344205 & 7200.20 & 3515.50 \\
\hline A1140 & Takiankangas & Granodiorite & 344104 & 7160.84 & 3517.17 \\
\hline A1256 & Takiankangas & Granite & 344104 & 7160.84 & 3517.17 \\
\hline A1274 & Kukkolankangas & Grey gneiss & 344101 & 7160.42 & 3509.10 \\
\hline A1275 & Kukkolankangas & Tonalite pegmatite & 344101 & 7160.42 & 3509.10 \\
\hline A1321 & Pelttari & Granite pegmatite & 353108 & 7238.78 & 3521.20 \\
\hline A1322 & Yli-Tontti & Granite & 353108 & 7232.74 & 3524.06 \\
\hline A1323 & Sotkavaara & Granite & 353106 & 7245.40 & 3517.42 \\
\hline
\end{tabular}


exhibits tight $\mathrm{F}_{3}$ folds and intense $\mathrm{D}_{4}$ shearing.

Sample A1140. (Takiankangas tonalite) comes from the centre of the OSZ and represents a slightly deformed tonalite dyke with no $\mathrm{D}_{1}$ and $\mathrm{D}_{2}$ structures. It exhibits, however, a penetrative and well visible $\mathrm{S}_{4}$ foliation.

Sample A1274 (Kukkolankangas grey gneiss) represents the Archaean Manamansalo complex at the centre of the OSZ. The sample is from a grey biotite-hornblende tonalite gneiss with metamorphic banding and complex deformation structures typical for the gneisses in Archaean areas.

Sample A1275 (Kukkolankangas tonalite pegmatite) is also from the Manamansalo complex, from the same locality as the previous sample. It represents an undeformed coarse-grained tonalitic pegmatite which penetrates a migmatic gneiss showing complex deformation structures.

The undeformed granites and pegmatites were emplaced during and after the $\mathrm{D}_{3}$ and $\mathrm{D}_{4}$ shearing events and are of granitic composition. They exist as dykes and wider elongated bodies trending parallel to the shear zones (Kärki \& Laajoki 1990). Some of them intersect $D_{3}$ and $D_{4}$ fault structures and penetrate their fault rocks. It was thus anticipated that such samples would give a minimum age for the development of the $\mathrm{D}_{4}$ deformation within the Oulujärvi and Hirvaskoski Shear Zones.

Sample A1008 (Kivivaara granite pegmatite) is from the Hirvaskoski Shear Zone and represents a coarse-grained granite pegmatite which looks like typical Palaeoproterozoic pegmatites.

Sample A1256 (Takiankangas granite) is from a medium-grained biotite granite with local cataclasite zones created by Postsvecokarelian faulting.

Sample A1321 (Pelttari granite pegmatite) is from an undeformed coarse-grained pegmatite granite which exhibits clear magmatic textures. The only secondary feature is caused by Postsvecokarelian brittle faulting.

Sample A1322 (Yli-Tontti granite) is a foliated, medium-grained two mica granite. The sample represents a N-S striking, c. $15 \mathrm{~m}$ wide gneissose granite, which follows the regional trend of $\mathrm{S}_{3}$ foliation but does not obviously penetrate $\mathrm{D}_{3}$ or $\mathrm{D}_{4}$ fault structures.

\section{ANALYTICAL PROCEDURES}

The rocks were crushed and the heavy minerals separated using heavy liquids and a Frantz isodynamic magnetic separator. The final separation was accomplished using Clerici's solution, which can theoretically attain a density of $4.6 \mathrm{~g} / \mathrm{cm}^{3}$ when heated in a waterbath. In practice, standard solutions of $3.8,4.0,4.2,4.3$ and $4.5 \mathrm{~g} / \mathrm{cm}^{3}$ were used. To assist hand picking, the samples were usually sieved at mesh sizes of 160 and $70 \mu \mathrm{m}$. Only the non-magnetic fractions $\left(1.4 \mathrm{~A}, 1^{\circ}\right.$ tilt) were used.

The procedure was to take a part of the heaviest (and least metamict) zircon fraction for air abrasion (Krogh 1982) in order to produce more concordant data, and to analyse 2-3 lighter fractions to give a useful downward extrapolation of the discordia. As monazite is usually very little discordant, single fractions of this mineral were used. Both the zircon and monazite fractions were subjected to hydrothermal combustion and the lead and uranium purified by anion exchange techniques using the method of Krogh (1973). Discordia chords were fitted to the data set using the Isoplot/Ex program (Ludwig 1998). For analyses done before 1991 using separate uranium and lead spikes, minimum errors $(0.65 \%$ for the $\mathrm{Pb} / \mathrm{U}$ ratios, $0.15 \%$ for the ${ }^{207} \mathrm{~Pb} /{ }^{206} \mathrm{~Pb}$ ratio and 0.97 for the error correlation) were applied and the calculated errors used only when they exceeded this limit. All error estimates are given at a $2 \sigma$ confidence level.

\section{RESULTS}

The analytical results are presented in Table 2 and on concordia diagrams in Figs. 3-5. The results may be assessed technically in the following manner:

\section{Deformed granitoids from the Hirvaskoski Shear Zone}

A1074-Kuvajavaara paragneiss. The four fractions scatter in excess of the analytical error 
Table 2. U-Pb mineral analyses from the Puolanka area.

\begin{tabular}{lc} 
Fraction & $\begin{array}{c}\text { Weigth } \\
(\mathrm{mg})\end{array}$ \\
\hline A597-Saariaho granite \\
A. $+4.2 /-200$ & 15.1 \\
B. $+4.0 /+200$ & 22.2 \\
C. +4.0 & 17.3 \\
D. 3.8-4.0 & 13.5 \\
E. $+4.2 /$ abr 3 h & 7.0
\end{tabular}

\section{A1008-Kivivaara pegmatite}

$\begin{array}{ll}\text { A. }+4.0 / \text { brown } & 4.2 \\ \text { B. } 4.3-4.6 & 8.7 \\ \text { C. } 4.2-4.3 & 3.1 \\ \text { D. } 4.0-4.2 & 6.1\end{array}$

3.1

$6.1 \quad 1397.3$

$\mathrm{U}$ conc

(ppm)

\section{7}

718.3

697.0

939.2

612.0

A1071-Avainlampi gneissose diorite
A. $4.3-4.5$
B. $4.0-4.2$

$0.6 \quad 1146.2$

0.5

0.4

864.0

5334.1

A1074-Kuvajavaara paragneiss

$\begin{array}{ll}\text { A. }+4.5 & 5.6 \\ \text { B. } 4.3-4.5 /+200 & 5.4 \\ \text { C. } 4.2-4.3 & 6.2 \\ \text { D. } 4.3-4.5 /-200 & 10.0\end{array}$

A1140-Takiankangas tonalite dyke

$\begin{array}{ll}\text { A. } 4.0-4.2 / \text { abr } 3 \text { h } & 8.4 \\ \text { B. } 4.0-4.2 & 7.0 \\ \text { C. } 3.8-4.0 /-200 & 6.8 \\ \text { D. } 3.8-4.0 /+200 & 7.0 \\ \text { E. } 3.6-3.8 & 7.2 \\ \text { F. Monazite } & 3.0\end{array}$

A1256-Takiankangas granite

$\begin{array}{ll}\text { A. } 4.3-4.5 / \mathrm{abr} 3 \mathrm{~h} & 6.3 \\ \text { B. } 4.3-4.5 & 7.0 \\ \text { C. } 4.2-4.3 & 5.4 \\ \text { D. } 4.0-4.2 & 5.8\end{array}$

A1274-Kukkolankangas grey gneiss

$\begin{array}{ll}\text { A. }+4.5 / \mathrm{abr} 3 \mathrm{~h} & 6.9 \\ \text { B. }+4.5 & 6.6\end{array}$

A1275-Kukkolankangas pegmatite
A. $+4.5 / \mathrm{abr} 3 \mathrm{~h}$
6.1
B. +4.5
6.4

103.2
167.4
340.7
176.4

$\mathrm{Pb}$ conc

(ppm)

$\begin{array}{rr}767.0 & 283.7 \\ 541.4 & 244.0 \\ 846.1 & 346.8 \\ 1397.3 & 449.8\end{array}$

120.0
116.5
117.4
148.0
226.7

742.3
256.7

4950.5

\section{5}

83.7
150.1

150.1

85.6

1745.9

1652.6

2088.7

1979.7

2190.7

2040.3

613.2
574.9
674.2
629.5
613.5
5521.2

$600.5 \quad 230.6$

621.6

786.4

978.9

$$
\begin{aligned}
& 240.6 \\
& 304.0
\end{aligned}
$$

341.6

155.6

154.4

98.3

96.9

92.1

152.0

150.0

91.6

1764.9

1609.8

1471.5

2545.0

538.1

497.1

476.0

6733.4

D. Monazite

2.0

A1322-Yli-Tontti gneissose granite

$\begin{array}{ll}\text { A. } 4.3-4.5 / \text { abr } 6 \mathrm{~h} & 5.6 \\ \text { B. } 4.3-4.5 & 5.3 \\ \text { C. } 4.2-4.3 & 6.0 \\ \text { D. } 4.0-4.2 & 7.1 \\ \text { E. Monazite } & 2.5\end{array}$

\section{4}

638.4

831.5

1099.2

1087.8

211.4
211.4
262.0
334.0
7472.3

412.8

464.4

478.3

606.8

433.5

6.1

7.0

6.2

$\begin{array}{ll}\text { D. } 4.2-4.3 & 6.2 \\ \text { E. large rounded } & 2.5\end{array}$

$\mathrm{U} / \mathrm{Pb}$ ratios corrected for fractionation and common lead

Common lead correction: 206/204: 15.7; 207/204: 15.4; 208/204: 35.4 for Proterozoic samples

206/204: 13.4; 207/204: 14.6; 206/204: 33.2 for Archean samples
${ }^{206} \mathrm{~Pb} / 204 \mathrm{~Pb}$

measured

${ }^{208} \mathrm{~Pb} /{ }^{206} \mathrm{~Pb}$

radiogenic

${ }^{206} \mathrm{~Pb} /{ }^{238} \mathrm{U}$

$\pm 2 \mathrm{SE}$

(\%)

490
790
725
413
618

0.208

0.165

0.158

0.238

0.183

0.2850

0.2865

0.2853

0.2526

0.3064

1.26

1.54

1.09

1.54

0.63

2869

6425

0.108

0.119

0.3350

0.65

4763

0.099

0.4037

0.65

0.107

0.3737

1.79

1.90

1.353

0.129

0.3001

0.65

1359

24000

2.251

0.2618

2.29

0.65

0.140

0.4716

0.65

0.105

0.4409

0.73

1635

1401

0.104

0.4250

0.65

0.65

0.168

0.159

0.3148

0.88

2141

2322

0.180

0.3096

0.2841

0.65

0.175

0.2798

0.2443

0.65

1841

0.185

0.2991

0.65

0.65

0.65

0.3109

0.3071

0.2870

0.2734

0.65

0.65

0.65

0.65

0.263

0.66

0.5138

0.66
0.65

10683

0.238
0.237

0.5117

0.65

6512

0.209

0.5062

0.65

4535

2847

0.050

0.047

0.084

8.430

0.3020
0.3037

0.61

1722

0.3038

0.59

0.61

0.65

\section{6}

0.086

0.146

0.088

0.087

23.960

0.3085

0.58

7988

0.3021

0.58

4721

0.3037

0.60

6056

0.2919

0.59

0.65

$\begin{array}{lllll}141.5 & 2531 & 0.152 & 0.3089 & 0.58 \\ 157.8 & 3401 & 0.104 & 0.3192 & 0.59 \\ 159.3 & 3045 & 0.119 & 0.3092 & 0.59 \\ 201.9 & 1709 & 0.102 & 0.3083 & 0.60 \\ 161.9 & 2715 & 0.080 & 0.3513 & 0.58\end{array}$

0.58

59
59

0.58 


\begin{tabular}{|c|c|c|c|c|c|c|c|}
\hline${ }^{207} \mathrm{~Pb} /{ }^{235} \mathrm{U}$ & $\begin{array}{l} \pm 2 \mathrm{SE} \\
(\%)\end{array}$ & ${ }^{207} \mathrm{~Pb} /{ }^{206} \mathrm{~Pb}$ & $\begin{array}{l} \pm 2 \mathrm{SE} \\
(\%)\end{array}$ & Corr. & $\mathrm{T}_{206 / 238}$ & $\mathrm{~T}_{207 / 235}$ & $\mathrm{~T}_{207 / 206}$ \\
\hline 4.273 & 1.31 & 0.1087 & 0.23 & 0.98 & 1616 & 1687 & 1778 \\
\hline 4.428 & 1.63 & 0.1121 & 0.29 & 0.98 & 1623 & 1717 & 1833 \\
\hline 4.409 & 1.16 & 0.1121 & 0.29 & 0.97 & 1617 & 1714 & 1833 \\
\hline 3.772 & 1.64 & 0.1083 & 0.33 & 0.98 & 1452 & 1586 & 1770 \\
\hline 4.671 & 0.63 & 0.1106 & 0.41 & 0.85 & 1722 & 1762 & 1809 \\
\hline 7.060 & 0.65 & 0.1528 & 0.20 & 0.95 & 1862 & 2119 & 2378 \\
\hline 9.404 & 0.65 & 0.1689 & 0.53 & 0.67 & 2186 & 2378 & 2547 \\
\hline 8.365 & 1.82 & 0.1623 & 0.15 & 0.99 & 2046 & 2271 & 2480 \\
\hline 6.288 & 1.92 & 0.1448 & 0.15 & 0.99 & 1765 & 2016 & 2285 \\
\hline 5.284 & 0.65 & 0.1277 & 0.15 & 0.97 & 1691 & 1866 & 2067 \\
\hline 5.331 & 2.29 & 0.1477 & 0.43 & 0.98 & 1499 & 1873 & 2319 \\
\hline 4.850 & 0.65 & 0.1102 & 0.15 & 0.97 & 1785 & 1793 & 1803 \\
\hline 11.803 & 0.65 & 0.1815 & 0.15 & 0.97 & 2490 & 2588 & 2666 \\
\hline 10.852 & 0.72 & 0.1785 & 0.15 & 0.97 & 2354 & 2510 & 2639 \\
\hline 9.652 & 0.65 & 0.1765 & 0.15 & 0.97 & 2153 & 2402 & 2620 \\
\hline 10.392 & 0.65 & 0.1773 & 0.15 & 0.97 & 2283 & 2470 & 2628 \\
\hline 4.914 & 0.88 & 0.1132 & 0.15 & 0.99 & 1764 & 1804 & 1851 \\
\hline 4.918 & 0.65 & 0.1152 & 0.15 & 0.97 & 1738 & 1805 & 1883 \\
\hline 4.363 & 0.65 & 0.1114 & 0.29 & 0.90 & 1611 & 1705 & 1822 \\
\hline 4.309 & 0.65 & 0.1117 & 0.15 & 0.97 & 1590 & 1695 & 1827 \\
\hline 3.711 & 0.65 & 0.1102 & 0.15 & 0.97 & 1408 & 1573 & 1802 \\
\hline 4.547 & 0.65 & 0.1103 & 0.15 & 0.97 & 1686 & 1739 & 1804 \\
\hline 4.684 & 0.65 & 0.1093 & 0.15 & 0.97 & 1745 & 1764 & 1787 \\
\hline 4.633 & 0.65 & 0.1094 & 0.26 & 0.92 & 1726 & 1755 & 1790 \\
\hline 4.276 & 0.65 & 0.1081 & 0.45 & 0.76 & 1626 & 1688 & 1767 \\
\hline 4.058 & 0.65 & 0.1077 & 0.24 & 0.93 & 1557 & 1645 & 1760 \\
\hline 12.924 & 0.67 & 0.1824 & 0.15 & 0.97 & 2672 & 2674 & 2675 \\
\hline 12.872 & 0.65 & 0.1825 & 0.15 & 0.97 & 2663 & 2670 & 2675 \\
\hline 12.621 & 0.65 & 0.1808 & 0.15 & 0.97 & 2640 & 2651 & 2660 \\
\hline 12.707 & 0.65 & 0.1812 & 0.15 & 0.97 & 2651 & 2658 & 2663 \\
\hline 4.583 & 0.61 & 0.1101 & 0.08 & 0.99 & 1700 & 1746 & 1801 \\
\hline 4.678 & 0.59 & 0.1117 & 0.08 & 0.99 & 1709 & 1763 & 1827 \\
\hline 4.814 & 0.61 & 0.1149 & 0.08 & 0.99 & 1710 & 1787 & 1879 \\
\hline 4.807 & 0.65 & 0.1091 & 0.20 & 0.95 & 1787 & 1786 & 1784 \\
\hline 4.693 & 0.59 & 0.1103 & 0.12 & 0.98 & 1733 & 1765 & 1805 \\
\hline 4.564 & 0.59 & 0.1096 & 0.09 & 0.98 & 1701 & 1742 & 1792 \\
\hline 4.610 & 0.60 & 0.1101 & 0.08 & 0.99 & 1709 & 1751 & 1801 \\
\hline 4.399 & 0.60 & 0.1093 & 0.08 & 0.99 & 1651 & 1712 & 1787 \\
\hline 4.796 & 0.65 & 0.1101 & 0.48 & 0.73 & 1769 & 1784 & 1801 \\
\hline 4.789 & 0.58 & 0.1124 & 0.16 & 0.97 & 1735 & 1782 & 1839 \\
\hline 5.084 & 0.59 & 0.1155 & 0.10 & 0.98 & 1786 & 1833 & 1888 \\
\hline 4.778 & 0.59 & 0.1121 & 0.10 & 0.98 & 1736 & 1780 & 1833 \\
\hline 4.836 & 0.60 & 0.1138 & 0.10 & 0.98 & 1732 & 1791 & 1860 \\
\hline 6.465 & 0.59 & 0.1335 & 0.13 & 0.98 & 1940 & 2041 & 2144 \\
\hline
\end{tabular}



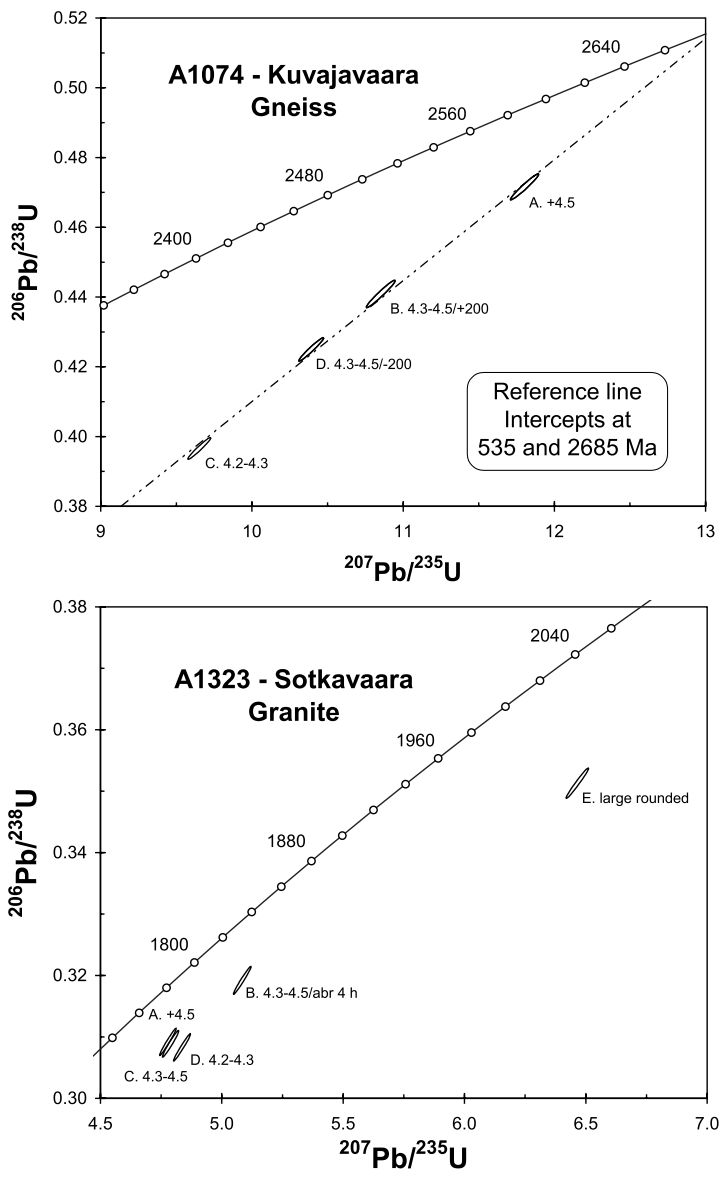

Fig. 3. Concordia diagrams for deformed granitoids from the Hirvaskoski shear zone (HSZ). Note that the different diagrams have different scales.

(MSWD=21), but exhibit the discordancy pattern usually encountered in granitic rocks, i.e. the degree of discordancy increases with increasing uranium content and decreasing density. The upper intercept age of a reference line is $2685 \mathrm{Ma}$. If the most discordant analysis (C) with a low ${ }^{208} \mathrm{~Pb} /{ }^{206} \mathrm{~Pb}$ (and hence original $\mathrm{Th} / \mathrm{U}$ ) ratio is excluded, the remaining three analyses define a discordia line with an MSWD of 1.6 and intercepts at $2699 \pm 9$ and $709 \pm 76 \mathrm{Ma}$. In any case, no Proterozoic event is discernible in the zircons of this rock.

A1323-Sotkavaara banded granite. The zircons from this rock scatter randomly, the fraction consisting of large rounded crystals being definitely older than the rest.

\section{Deformed granitoids from the Oulujärvi Shear Zone}

A597-Saariaho granite. The five fractions analysed scatter fairly randomly on the concordia diagram, and no age calculation is feasible. The data only show that the rock consists of inherited material containing zircons partially reset in Palaeoproterozoic times.

A1071-Avainlampi diorite. The pure zircon fraction (B) is highly discordant and obviously represents material inherited from a probable Archaean source. Judging from the elevated ${ }^{208} \mathrm{~Pb} /$ ${ }^{206} \mathrm{~Pb}$ ratio, fraction $\mathrm{A}$ is a zircon-monazite mixture. The monazite is almost concordant, and its ${ }^{207} \mathrm{~Pb} /{ }^{206} \mathrm{~Pb}$ age, $1803 \pm 3 \mathrm{Ma}$, gives the time of the last cooling to under $600^{\circ} \mathrm{C}$.

A1140-Takiankangas tonalite. The monazite is discordant, with a ${ }^{207} \mathrm{~Pb} /{ }^{206} \mathrm{~Pb}$ age of $1804 \pm 3 \mathrm{Ma}$. The five zircon fractions scatter well in excess of the analytical error. When the obviously deviating fraction B is eliminated, the remaining four plot along a reference line with an upper intercept at $1860 \mathrm{Ma}$.

A1274-Kukkolankangas grey gneiss. Of the two fractions analysed, the abraded one is concordant within the margins of experimental error. Consequently its ${ }^{207} \mathrm{~Pb} /{ }^{206} \mathrm{~Pb}$ age, $2675 \pm 2 \mathrm{Ma}$, may be regarded as suggesting either the time of intrusion or that of a high-grade Archaean metamorphism.

A1275-Kukkolankangas tonalite pegmatite. Both fractions are practically concordant, and the ${ }^{207} \mathrm{~Pb} /{ }^{206} \mathrm{~Pb}$ age of fraction $\mathrm{B}, 2663 \pm 2 \mathrm{Ma}$, may be considered to denote the time of emplacement.

\section{Undeformed granitoids}

A1008-Kivivaara granite pegmatite. The four fractions exhibit a normal discordancy pattern, and define a reasonably good linear trend $(\mathrm{MSWD}=1.6)$ which intercepts the concordia curve at $2724 \pm 28$ Ma. The lower intercept is rather high at $1113 \mathrm{Ma}$, but both this and the largish error estimate may be combined effects of the relatively large degree of discordancy and the rather small dispersion of the fractions analysed.

A1256-Takiankangas granite. The four zircon fractions exhibit a normal discordancy pattern and 
a scatter only slightly in excess of the experimental error (MSWD=1.8). The upper intercept age is $1795 \pm 5 \mathrm{Ma}$ and may be taken to represent the time of emplacement of this rock.

A1321-Pelttari granite pegmatite. The monazite is concordant within the margins of experimental error, and its age, $1786 \pm 5 \mathrm{Ma}$, may be considered to represent the last cooling to below the $600^{\circ} \mathrm{C}$ isotherm. The three zircon fractions are apparently inherited.

A1322-Yli-Tontti granite. If the fraction B with a deviating ${ }^{208} \mathrm{~Pb} /{ }^{206} \mathrm{~Pb}$ ratio (probably indicating the presence of some monazite in the analysis) is excluded, the remaining three zircon fractions scatter within the bounds of experimental error (MSWD=0.23) and give an upper intercept of $1822 \pm 7 \mathrm{Ma}$, which may be considered the best estimate for the emplacement of the pegmatite. The ${ }^{207} \mathrm{~Pb} /{ }^{206} \mathrm{~Pb}$ age of the slightly discordant monazite, $1801 \pm 5 \mathrm{Ma}$, may be considered to reflect the last cooling of the rock below $600^{\circ} \mathrm{C}$.

\section{DISCUSSION}

The results derived from the analytical data are summarized in Table 3, from which several general features can be seen. Four of the samples analysed contain heterogeneous zircons which do not

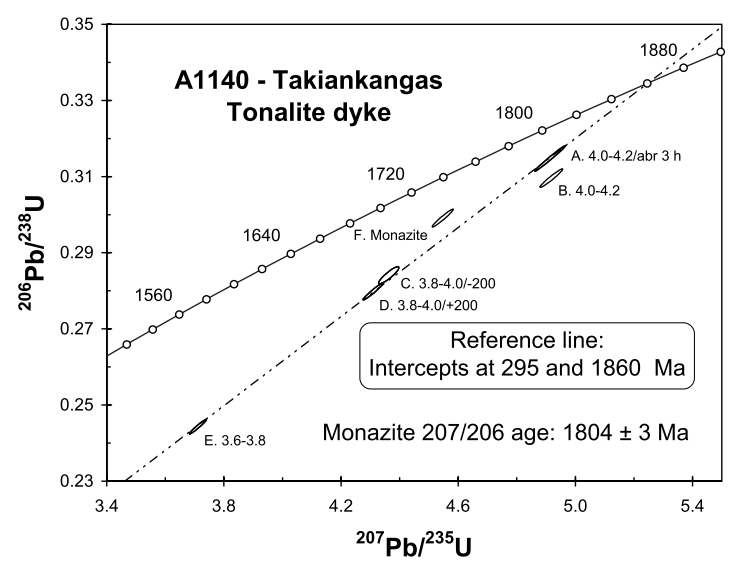

facilitate any sort of age calculation. According to field evidence, A597 Saariaho, A1071 Avainlampi, A1321 Pelttari and A1323 Sotkavaara are presumably of Palaeoproterozoic age, but all of them contain inherited zircons, and the pure zircon fraction from A1071 could be of Archaean origin and may have suffered a loss of radiogenic lead during the c. 1800 Ma event indicated by the monazite of the same sample.

For samples A1140 Takiankangas and A1074 Kuvajavaara reference lines giving minimum ages for the zircon populations in question can be constructed. However, it should be emphasized that these estimates are not necessarily related to the emplacement of the rocks and may have been affected by later tectonometamorphic events.
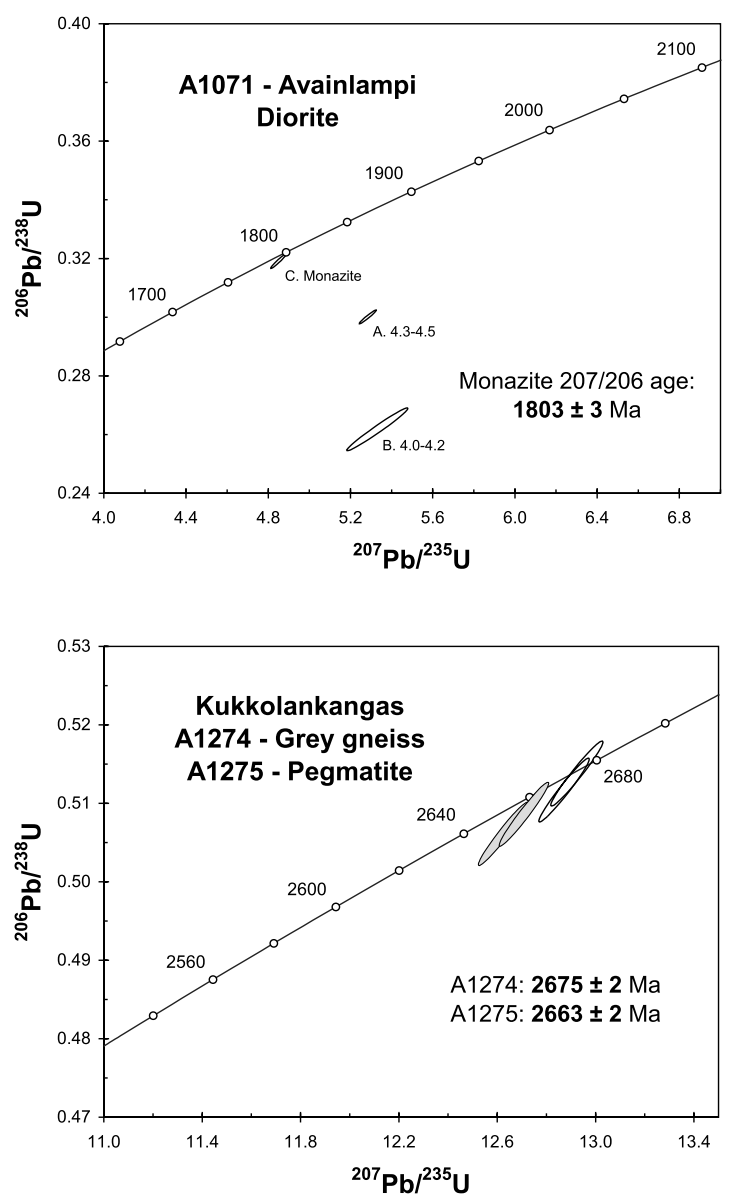

Fig. 4. Concordia diagrams for deformed granitoids from the Oulujärvi shear zone (OSZ). 

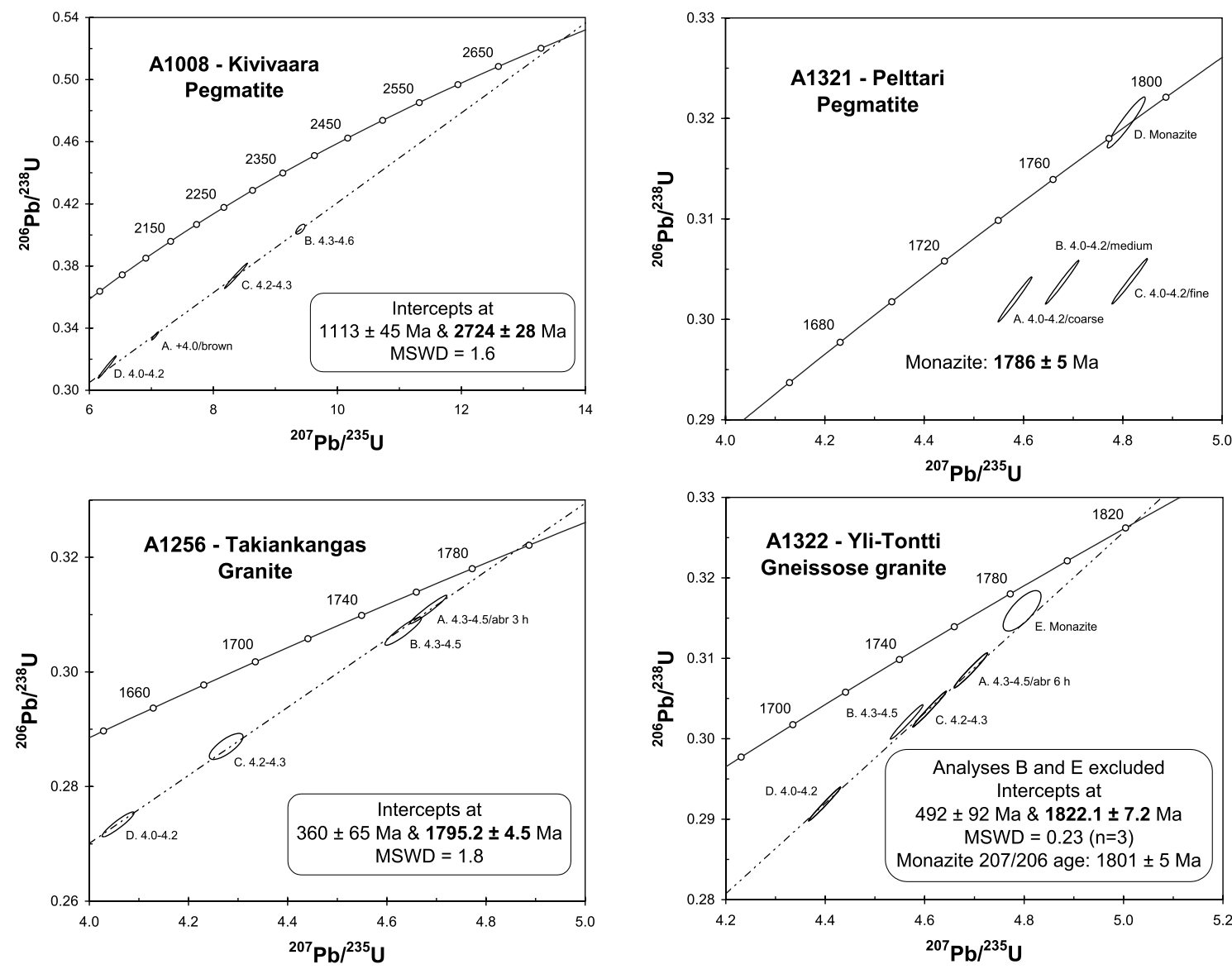

Fig. 5. Concordia diagrams for undeformed granitoids from the study area.

Samples A1008 Kivivaara, A1074 Kuvajavaara, A1274 Kukkolankangas and A1275 Kukkolankangas contain definitely Archaean zircons, but only the samples from Kukkolankangas, representing the Manamansalo Complex, can be regarded to give true emplacement ages as their zircons are concordant. The others exhibit either relatively large MSWD values or one or more deviating fractions. However, these samples yield ages of the kind often recorded in the Finnish Archaean terrain (2750-2720 Ma; cf. Vaasjoki et al. 1993, 1999 and references therein), and the ca. $2670 \mathrm{Ma}$ episode apparent in the Kukkolankangas samples has also been recorded previously (ibid.), especially in titanites, but also in zircons.

Rocks exhibiting Proterozoic zircons are A1140
Takiankangas, A1256 Takiankangas and A1322 Yli-Tontti, which lie within the Hirvaskoski and Oulujärvi Shear Zones. Of these three, only two - A1256 and A1322 - can be regarded as giving valid age estimates.

All monazites analysed are Proterozoic, and three of them, A1071, A1140 and A1322, have ${ }^{207} \mathrm{~Pb} /{ }^{206} \mathrm{~Pb}$ ages identical within the margins of experimental error, at $1800 \mathrm{Ma}$, while the fourth, A1321, is slightly but significantly younger.

The analytical results prove beyond doubt that Archaean crust was reworked to varying degrees within the Palaeoproterozoic shear zones. Thus the samples from the Manamansalo Complex, which is an Archaean passive block within the OSZ, show typical Archaean deformation and yield con- 
Table 3. Summary of granitoid $U$-Pb ages from the Puolanka area.

\begin{tabular}{lllll}
\hline Sample & & Intercept $(M a)$ & MSWD & Comment \\
\hline A597 & Granite & heterogeneous & & \\
A1008 & Pegmatite & $2724 \pm 28$ & 1.6 & $4 / 4$ fractions \\
A1071 & Diorite & heterogeneous & & Monazite $1803 \pm 3$ \\
A1074 & Gneiss & 2685 & & Reference line \\
A1140 & Tonalite & 1860 & 1.8 & Monazite $1804 \pm 4$ \\
A1256 & Granite & $1796 \pm 5$ & - & concordant \\
A1274 & Grey gneiss & $2675 \pm 2$ & - & concordant \\
A1275 & Pegmatite & $2663 \pm 2$ & & Monazite $1786 \pm 5$ \\
A1321 & Gneissose granite & heterogeneous & 0.23 & $3 / 4 ;$ MZ $1801 \pm 9$ \\
A1322 & Pegmatite & $1822 \pm 7$ & &
\end{tabular}

cordant zircon data. On the other hand, the Kivivaara pegmatite, which cross-cuts all Proterozoic deformation structures, also exhibits definitely Archaean zircons. A structurally intermediate case is the Kuvajavaara gneiss, exhibiting clear $\mathrm{D}_{3}$ but no $\mathrm{D}_{4}$ structures and containing Archaean zircons.

The samples containing heterogeneous zircons are also of variable tectonic character. The Avainlampi diorite dyke is conformable with an $\mathrm{F}_{3}$ fold, and the Saariaho and Sotkavaara granites exhibit $\mathrm{S}_{4}$ foliations, while the Yli-Tontti granite is less deformed. At least at Avainlampi, and most likely also in the other three cases, the zircons are inherited, incompletely reset Archaean material, although this should be verified by whole rock Sm$\mathrm{Nd}$ and zircon SIMS analyses.

Both the Yli-Tontti (A1322) and the Takiankangas (A1256) granites are undeformed, and yield ages of $1822 \pm 7$ and $1795 \pm 5 \mathrm{Ma}$, respectively. This suggests that, as in the Salahmi area (Pietikäinen \& Vaasjoki 1999), deformation within the shear zones had ceased by $1820 \mathrm{Ma}$ at the latest, and no magmatic activity occurred later than about $1800 \mathrm{Ma}$ ago. The fact that three of the four analysed monazites exhibit ages close to $1800 \mathrm{Ma}$ suggests a fairly wide extent of the thermal pulse responsible for the Takiankangas granite.

As the temperature required for the total resetting of the U-Pb system in zircon is $750-800^{\circ} \mathrm{C}$ (eg. Vaasjoki \& Sakko 1988), the occurrence of inherited Archaean zircons in demonstrably Palaeoproterozoic rocks shows that many granitoid magmas intruding the Hirvaskoski and Oulujärvi shear zones were formed below that temperature. That inherited zircons are met within granitoids of all possible tectonic stages suggests surprisingly stable thermodynamic conditions during the shear zone evolution.

\section{CONCLUSIONS}

The Kainuu terrain was evidently influenced by the Svecokarelian orogeny and may have behaved as an active zone already during its earliest phases. All rocks associated with both $\mathrm{D}_{3}$ and $\mathrm{D}_{4}$ stages of deformation contain inherited, partially reset zircon populations. However, rocks containing definitely Archaean zircons demonstrate, that the intensity of the reworking varied locally. On the other hand, neither the granites yielding zircon ages of $1.82 \mathrm{Ga}$ nor the slightly younger $1.8 \mathrm{Ga}$ rocks show any features associated with the Palaeoproterozoic shearing events, and thus give a minimum age for deformation stage $\mathrm{D}_{4}$. Thus the $1.80 \mathrm{Ga}$ age marks the end of the orogenic evolution in the central Fennoscandian Shield.

Monazites around $1800 \mathrm{Ma}$ in age are typical of the granitoids of the central part of the OSZ and the southern part of the HSZ and mark the end of significant thermal activity as well as the beginning of a period of rapid cooling terminating the Svecokarelian orogenic evolution. The $1786 \mathrm{Ma}$ age of the monazites in the northernmost sample 
suggest that the cooling took place more slowly in the terrains close to the large Kemijärvi Complex than in the areas further south.

\section{ACKNOWLEDGEMENTS. This study forms part} of a joint effort of the Geological Survey of Finland (GTK) and the University of Oulu $(O Y)$ to better understand the geology in the Puolanka area. We wish to thank the technical staff of GTK for assistance during the analytical work. The maps were drafted by Mrs. Kristiina Karjalainen. Discussions with Hannu Huhma, Kalevi Korsman and Asko Kontinen (GTK) as well as Pekka Tuis$k u(O Y)$ helped to clarify the at times hazy reasoning of the first author. Constructive criticism from the referees, Professor Carl Ehlers (Åbo Akademi) and, in particular, Dr. Karin Högdahl (Stockholms Universitet), materially improved the submitted draft of this paper.

\section{REFERENCES}

Barbey, P. \& Martin, H. 1987. The role of komatiites in plate tectonics. Evidence from the Archaean and early Proterozoic crust in eastern Baltic Shield. Precambrian Research 35, 1-14.

Claesson, S., Huhma, H., Kinny, P.D. \& Williams, I.S. 1993. Svecofennian detrital zircon ages - implications for the Precambrian evolution of the Baltic Shield. Precambrian Research 64, 109-130.

Gaál, G. \& Gorbatschev, R. 1987. An outline of the evolution of the Baltic Shield. Precambrian Research 35, $15-52$.

Gorbatschev, R. \& Bogdanova, S. 1993. Frontiers in the Baltic Shield. Precambrian Research 64, 3-21.

Guglielmo, G. 1993. Interference between pluton expansion and non-coaxial tectonic deformation: three-dimensional computer model and field implications. Journal of Structural Geology 15, 593-608.

Hanski, E. 1993. Petrology of the Pechenga ferropicrites and cogenetic, Ni-bearing gabbro-wehrlite intrusions, Kola Peninsula, Russia. Geological Survey of Finland, Bulletin 367. 192 p.

Horneman, R., Hyvärinen, T. \& Niskanen, P. 1988. The granitoids surrounding and intruding the Kuhmo greenstone belt in Finland. Geological Survey of Finland, Special Paper 4, 97-121.

Huhma, H. 1986. Sm-Nd, U-Pb and $\mathrm{Pb}-\mathrm{Pb}$ isotopic evidence for the origin of the early Proterozoic Svecokarelian crust in Finland. Geological Survey of Finland, Bulletin $337.52 \mathrm{p}$.
Huhma, H., Claesson, S., Kinny, P.D. \& Williams, I.S. 1991. The growth of early Proterozoic crust: new evidence from Svecofennian detrital zircons. Terra Nova 3, 175-179.

Hutton, D. \& Reavy, R. 1992. Strike-slip tectonics and granite petrogenesis. Tectonics 11, 960-967.

Hyppönen, V. 1983. Ontojoen, Hiisijärven ja Kuhmon kartta-alueiden kallioperä. Summary: Pre-Quaternary rocks of the Ontojoki, Hiisijärvi and Kuhmo mapsheet areas. Geological Map of Finland 1 : 100000. Explanation to the maps of Pre-Quaternary rocks, Sheets 4411, 4412, 4413. Geological Survey of Finland. $60 \mathrm{p}$.

Jahn, B-M., Vidal, P. \& Kröner, A. 1984. Multi-chronometric ages and origin of Archaean tonalitic gneisses in Finnish Lapland: a case for long crustal residence time. Contributions to Mineralogy and Petrology 86, 398-408.

Kähkönen, Y. 1989. Geochemistry and petrology of the metavolcanic rocks of the early Proterozoic Tampere Schist Belt, southern Finland. Geological Survey of Finland, Bulletin 345. 107 p.

Kahma, A. 1978. The main sulfide ore belt of Finland between Lake Ladoga and the Bothnian Bay. Bulletin of the Geological Society of Finland 50, 39-43.

Kärki, A. 1995. Palaeoproterozoic shear tectonics in the central Fennoscandian Shield, Finland. Res Terrae Serie A No. 10, University of Oulu, Finland.

Kärki, A. \& Laajoki, K. 1990. Puolanka. Geological map of Finland 1 : 100 000, Pre-Quaternary rocks, Sheet 3442. Geological Survey of Finland.

Kärki A. \& Laajoki, K. 1995. An interlinked system of folds and ductile shear zones - late stage Svecokarelian deformation in the central Fennoscandian Shield, Finland. Journal of Structural Geology 17, 1233-1247.

Kärki, A., Laajoki, K. \& Luukas J. 1993. Major Palaeoproterozoic shear zones of the central Fennoscandian Shield. Precambrian Research 64, 207-233.

Kesola, R. 1991. Metavolcanics and associated rocks in the northernmost Lapland (Finland). Geological Survey of Finland, Report of Investigation 107. 58 p.

Kohonen, J. \& Marmo, J. 1992. Proterozoic lithostratigraphy and sedimentation of Sariola and Jatuli-type in the Nunnanlahti-Koli-Kaltimo area, eastern Finland; implications for regional basin evolution models. Geological Survey of Finland, Bulletin 364. 67 p.

Korsman, K. (ed.) 1988. Tectono-metamorphic evolution of the Raahe-Ladoga zone, eastern Finland. Geological Survey of Finland, Bulletin 343. 96 p.

Krogh, T.E. 1973. A low-contamination method for hydrothermal decomposition of zircon and extraction of $U$ and $\mathrm{Pb}$ for isotopic age determinations. Geochimica et Cosmochimica Acta 37, 485-494.

Krogh, T.E. 1982. Improved accuracy of U-Pb zircon ages by the creation of more concordant systems using air abrasion technique. Geochimica et Cosmochimica Acta 46, 637-649.

Kröner, A., Puustinen, K. \& Hickman, M. 1981. Geochronology of an Archaean gneiss dome in northern Fin- 
land and its relation with an unusual overlying volcanic conglomerate and komatiite greenstone. Contributions to Mineralogy and Petrology 76, 33-41.

Laajoki, K. 1986. The Precambrian supracrustal rocks of Finland and their tectono-exogenic evolution. Precambrian Research 33, 67-85.

Laajoki, K. 1991. Stratigraphy of the northern end of the early Proterozoic (Karelian) Kainuu Schist Belt and associated gneiss complexes, Finland. Geological Survey of Finland, Bulletin 358. 105 p.

Lahtinen, R. \& Huhma, H. 1997. Isotopic and geochemical constraints on the evolution of the 1.93-1.79 Ga Svecofennian crust in Finland. Precambrian Research 82, 13-34.

Ludwig, K. 1998. Using Isoplot/Ex. Berkeley Geochronology Center, Special Publication 1. 43 p.

Luukas, J. 1991. Salahmin-Pyhännän alueen stratigrafia ja rakennegeologia. Res. Terrae, Ser B 16. 131 p.

Luukkonen, E.J. 1985. Structural and U-Pb isotopic study of the northern part of the late Archaean Kuhmo greenstone belt, eastern Finland. Transactions of the Royal Society of Edinburgh, Earth Sciences 76, 401-410.

Luukkonen, E.J. 1988. The structure and stratigraphy of the northern part of the late Archaean Kuhmo greenstone belt, eastern Finland. Geological Survey of Finland, Special Paper 4, 71-96.

Martin, H., Chauvel, C., Jahn, B-M. \& Vidal, P. 1983. Rb$\mathrm{Sr}$ and $\mathrm{Sm}-\mathrm{Nd}$ geochemistry of Archaean granodioritic gneisses from eastern Finland. Precambrian Research 20, 79-91.

Meriläinen, K. 1976. The granulite complex and adjacent rocks in Lapland, northern Finland. Geological Survey of Finland, Bulletin 281. 129 p.

Nironen, M. \& Front, K. 1992. The 1.88 Ga old Mäntylä complex, central Finland: emplacement and deformation of mafic to felsic plutonic rocks and associated Mo mineralization. Bulletin of the Geological Society of Finland 64, 75-90.

Nurmi, P. \& Haapala, I. 1986. The Proterozoic granitoids of Finland: granite types, metallogeny and relation to crustal evolution. Bulletin of the Geological Society of Finland 58, 203-233.

Paavola, J. 1986. A communication on the U-Pb and KAr age relations of the Archaean basement in the Lapinlahti-Varpaisjärvi area, central Finland. Geological Survey of Finland, Bulletin 339, 7-13.

Patchett, J. \& Kouvo, O. 1986. Origin of continental crust of 1.9-1.7 Ga age: $\mathrm{Nd}$ isotopes and $\mathrm{U}-\mathrm{Pb}$ zircon ages in the Svecokarelian terrain of south Finland. Contributions to Mineralogy and Petrology 92, 1-12.

Paterson, S. \& Tobisch, O. 1988. Using pluton ages to date regional deformations: problems with commonly used criteria. Geology 16, 1108-1111.

Pietikäinen, K. \& Vaasjoki, M. 1999. Structural observations and $\mathrm{U}-\mathrm{Pb}$ mineral ages from igneous rocks at the Archaean-Palaeoproterozoic boundary in the Salahmi schist belt, central Finland: constraints on tectonic evolution. Bulletin of the Geological Society of Finland 71, 133-142.

Scott, D., Machado, N., Hanmer, S. \& Gariépy, C. 1993. Dating ductile deformation using U-Pb geochronology: examples from the Gilbert River Belt, Grenville Province, Labrador, Canada. Canadian Journal of Earth Sciences 30, 1458-1469.

Simonen, A. 1980. The Precambrian in Finland. Geological Survey of Finland, Bulletin 304. 58 p.

Suominen, V. 1991. The chronostratigraphy of southwestern Finland with special reference to Postjotnian and Subjotnian diabases. Geological Survey of Finland, Bulletin $356.100 \mathrm{p}$.

Vaasjoki, M. 1996. Explanation to the geochronological map of southern Finland: The development of the continental crust with special reference to the Svecofennian orogeny. Geological Survey of Finland, Report of Investigation $135.30 \mathrm{p}$.

Vaasjoki, M. \& Sakko, M. 1988. The evolution of the Raahe-Ladoga zone in Finland: isotopic constraints. Geological Survey of Finland, Bulletin 343, 7-32.

Vaasjoki, M. \& Huhma, H. 1992. Radiometric ages of Finnish rocks. The Geochemical Atlas of Finland, Part 2: Till, 67-69.

Vaasjoki, M., Sorjonen-Ward, P. \& Lavikainen, S. 1993. $\mathrm{U}-\mathrm{Pb}$ age determinations and sulfide $\mathrm{Pb}-\mathrm{Pb}$ characteristics from the late Archaean Hattu schist belt, Ilomantsi, eastern Finland. Geological Survey of Finland, Special Paper 17, 103-131.

Vaasjoki, M., Taipale, K. \& Tuokko, I. 1999. Radiometric ages and other isotopic data bearing on the evolution of Archaean crust and ores in the Kuhmo-Suomussalmi area, eastern Finland. Bulletin of the Geological Society of Finland 71, 155-176.

Ward, P. 1987. Early Proterozoic deposition and deformation at the Karelian craton margin in southeastern Finland. Precambrian Research 35, 71-93.

Vuollo, J. 1994. Palaeoproterozoic basic igneous events in eastern Fennoscandian Shield between 2.45 and $1.97 \mathrm{Ga}$. Acta Universitatis Ouluensis, Serie A, No. 250. 